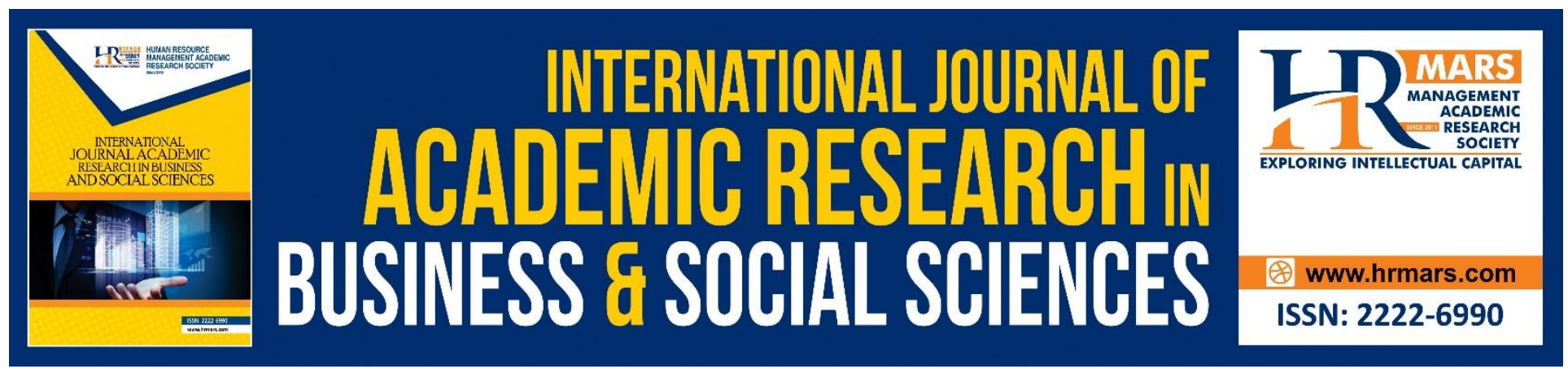

\title{
Teacher Leadership and its Relationship with High School Students' Performance in Malaysia
}

Hamidah Yusof, Haslinda Antisan, Mohd. Asri Mohd Noor, Mahaliza Mansur

To Link this Article: http://dx.doi.org/10.6007/IJARBSS/v10-i10/7742

DOI:10.6007/IJARBSS/v10-i10/7742

Received: 07 August 2020, Revised: 26 August 2020, Accepted: 18 September 2020

Published Online: 07 October 2020

In-Text Citation: (Yusof, Antisan, Noor, \& Mansur, 2020)

To Cite this Article: Yusof, H., Antisan, H., Noor, M. A. M., \& Mansur, M. (2020). Teacher Leadership and its Relationship with High School Students' Performance in Malaysia. International Journal of Academic Research in Business and Social Sciences. 10(10), 243-259.

\section{Copyright: (c) 2020 The Author(s)}

Published by Human Resource Management Academic Research Society (www.hrmars.com)

This article is published under the Creative Commons Attribution (CC BY 4.0) license. Anyone may reproduce, distribute, translate and create derivative works of this article (for both commercial and non-commercial purposes), subject to full attribution to the original publication and authors. The full terms of this license may be seen at: $\underline{\text { http://creativecommons.org/licences/by/4.0/legalcode }}$

Vol. 10, No. 10, 2020, Pg. 243 - 259

Full Terms \& Conditions of access and use can be found at http://hrmars.com/index.php/pages/detail/publication-ethics 


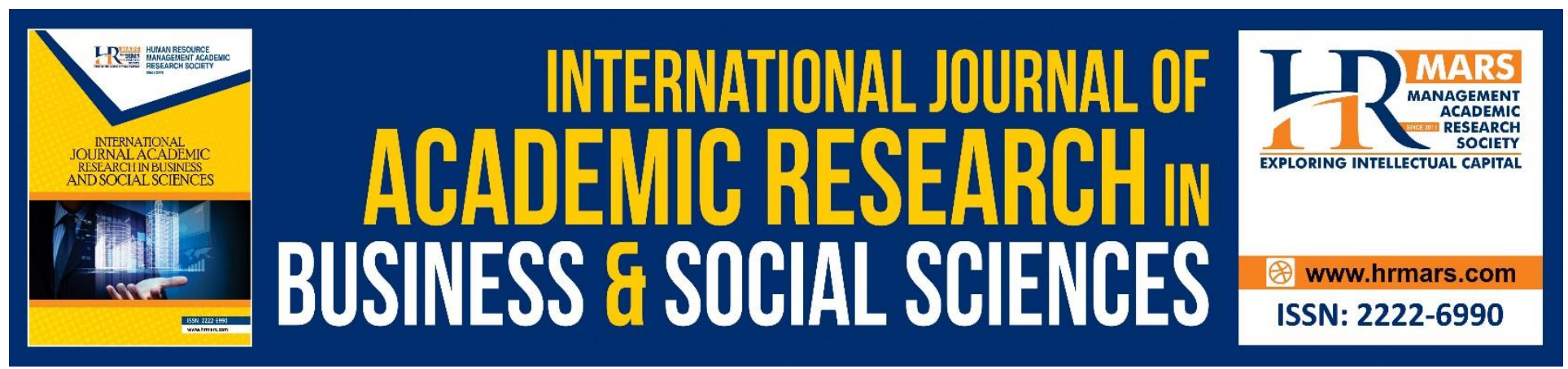

\title{
Teacher Leadership and its Relationship with High School Students' Performance in Malaysia
}

\author{
Hamidah Yusof \\ Professor, Faculty of Business and Education Management, Sultan Idris Educational University \\ 35900 Tanjong Malim, Perak, Malaysia. \\ Email: Hamidah.Yusof@fpe.upsi.edu.my
}

Haslinda Antisan

Postgraduate student, Faculty of Business and Education Management, Sultan Idris Educational University, 35900 Tanjong Malim, Perak, Malaysia.

Email: linda_antisan@yahoo.com.my

\section{Mohd. Asri Mohd Noor, Mahaliza Mansur \\ Senior Lecturer, Faculty of Business and Education Management, Sultan Idris Educational University 35900 Tanjong Malim, Perak, Malaysia. \\ Email: mohd.asri@fpe.upsi.edu.my,mahaliza@fpe.upsi.edu.my}

\begin{abstract}
The purpose of this study is to identify the relationship between teacher leadership and students' academic achievement in Malaysia secondary school. A questionnaire-based survey was conducted to gather data from 52 teachers. The data analysed using descriptive statistics and Pearson correlation tests. The findings obtained from the analyses showed that the mean score values for every dimension of teacher leadership factor a relatively moderate. The findings also show that there was a significant correlation relationship between the components of self-assessment and make changes, communication, diversity, teaching skills, continuous improvement and independent organisation in the teacher leadership model with students' academic performance. The dimension of teaching skills has a higher significant correlation to students' academic performance followed by an independent organisation, diversity, self-assessment and make a change, and the least significant correlation is the dimension of continuous improvement. This study suggests that teachers need to improve leadership practices to enhance students' academic performance.
\end{abstract}

Keywords: Teacher Leadership, Academic Achievement, High School Achievement, Students' Performance, School Leadership. 
INTERNATIONAL JOURNAL OF ACADEMIC RESEARCH IN BUSINESS AND SOCIAL SCIENCES Vol. 10, No. 10, 2020, E-ISSN: 2222-6990 @ 2020 HRMARS

\section{Introduction}

Teachers play a more prominent role as an agent to the educational transformation in the country. They act as an agent of change in the education system. Teachers are considered professionals and capable of meeting the changes that are desired by the community. The role of the teachers is becoming more important nowadays, especially in improving the quality of teaching and learning (Billingsley, 2007; Little, 2003). Teachers are the person who entrusted with improving the teaching quality and continuing the learning activities that ultimately meet the academic achievements of the students. Therefore, to maintain their quality of teaching and performance in other duties, teachers need to prepare themselves with basic leadership principles in meeting future challenges. Teachers should also be aware that they are the implementers of public education. Hence, teachers need to be competitive, high quality and, most importantly, be the leader of teaching (Katzenmeyer \& Moller, 2009).

School achievement always measured through the student's academic achievement and their success after graduation. The teacher's quality always related relative to students' achievements and performance. The duties and responsibilities of teachers are beyond teaching due to the development of the information era (Gunter, 2001). According to Ishak and Fin (2013), teachers with interesting personalities can entice their students to follow the teaching and learning process in the classroom. Contrary, if a teacher exhibits an emotionless attitude towards the students, the teaching and learning process will hence be disrupted. Therefore, teachers need to equip themselves with a variety of leadership-related knowledge to enable success in the process of students' academic achievement

Teachers with a superior leadership style can influence their students to change towards excellence. The direction and goals of the students who are taught by teachers with effective leadership styles are becoming more apparent (Hassan \& Mohd., 2011). They also capable of stimulating their students, of improving themselves towards excellence both in academics and personality. Different leadership styles are also capable of producing different results. This study is related to the studies of Barth (2001); Birky, Shelton and Headley (2006), who figured that excellent leadership could produce excellent students in terms of academic achievement. Leadership has a significant effect on student learning, and teacher leaders provide most of the leadership in schools (Leithwood \& Riehl, 2003). Therefore, teacher leadership is one of the essential aspects that assessed in the effective school formation.

However, there are a handful of teachers who still fail to perform high-quality leadership. Such teachers are assumed to have no vision and direction as they are only doing their job when directed by the principal. They cannot make their own decision and rely heavily on principals. These teachers, who have lower leadership qualities, are those who are only able to wait for the instructions to perform the given task. Many teachers are still unable to see themselves as leaders (Katzenmeyer \& Moller, 2001). Teachers with a high level of charisma and professionalism are drivers of school and student success. The personality, leadership and seriousness in teachers are the aspects that always assessed. Based on a study conducted by Yusof, Mat Min, Abdul Jalil, Mohd Noor, and Yusof (2018), there is a significant relationship between the factor of teacher leadership and students' academic achievement. Skilled teachers are capable of producing academically excellent students. The 
INTERNATIONAL JOURNAL OF ACADEMIC RESEARCH IN BUSINESS AND SOCIAL SCIENCES Vol. 10, No. 10, 2020, E-ISSN: 2222-6990 @ 2020 HRMARS

teachers' technique and method of teaching influenced the students' performance directly. However, some teachers do not show leadership and commitment values when delivering their responsibility as educators. The current trend shows that most teachers consider leadership only involves principals and higher ranks of administrators. In general, teachers have a high tendency to stereotype their function and implement only the basics roles in the classroom (Katzenmeyer \& Moller, 2001).

\section{Teacher Leadership}

Katzenmeyer and Moller (2009) outline six aspects of assessing teacher practices such as communication, transformation, diversity, teaching, improvement, and self-organisation. These six practices, supported with teachers' awareness (Harris, 2003), are capable of improving the effectiveness of a school in meeting the globalisation era. However, the lack of teachers' awareness might contribute to ineffectiveness and failure in implementing already planned activities (Katzenmeyer and Moller, 2009). Teachers need to be aware that they are involved in a collaborative process with the school community in improving students' academic achievement (York \& Barr, 2004). Lately, there are many issues related to disciplinary violations among students. The moral values among students are seen to be fading. This situation is associated with the failure of schools in producing balanced human beings. Teachers are said to be unsuccessful in fulfilling their responsibilities and resulted in poor leadership skills with the increase of social and moral problems among students. In relating to the aforementioned issue, the current study is conducted to identify the relationship between teachers' leadership practices and students' academic achievement. The fact that teachers are the agents of implementation in forming an effective school (Danielson, 2006) necessitates the need for the teachers to refine themselves with leadership practices to become a quality teacher (Katzenmeyer and Moller, 2009).

There are various concepts and views related to teacher leadership among different scholars. Teacher leadership refers to an effort to mobilise principals, peers, community members, and education-related parties in improving the teaching and learning process so that academic achievement can be improved. Lambert (2003) explained that teacher leadership occurs when all the school community has leadership skills in the process of improving the school. From another point of view, teacher leadership can be seen through collective teachers' collaboration in influencing other teachers to bring about changes to a school (York-Barr et al., 2004; Danielson, 2006). Danielson (2006) asserts that teacher leadership is not limited to classroom tasks only, but also to help the community out of the school area. Different leadership styles are the determinant of the success of an organisation. Katzenmeyer and Moller (2009) explain that teacher leadership refers to a teacher who is considered a leader in school and is responsible for the excellence of students' academic achievement. Teachers with leaders' characteristics have a proactive attitude and always trying to achieve their goals without waiting for the principal's instructions. They will do the entrusted assignments and responsibilities given to them without any complaints.

The dimensions of self-awareness and making changes are parts of the elements of leadership that every teacher must possess. By understanding their strengths and weaknesses, the teachers can reflect on improving themselves. Indirectly, teachers can take advantage of every strength they possess to overcome their weaknesses. This self-awareness of strengths and weaknesses quality makes a teacher become a good leader (Katzenmeyer and Moller, 2009). Positive changes will occur 
INTERNATIONAL JOURNAL OF ACADEMIC RESEARCH IN BUSINESS AND SOCIAL SCIENCES Vol. 10, No. 10, 2020, E-ISSN: 2222-6990 @ 2020 HRMARS

if each teacher, principal, and a colleague have self-awareness. To become a good leader, teachers need to understand the factors that influence the way they and their colleagues work, study, and change in school. All school agents work together towards improving school culture as well as achieving the school's vision and mission. Teachers' communication plays a vital role in creating a conducive classroom environment. Teachers need to have excellent communication skills to attract students and to stimulate an effective teaching and learning environment. Communication can occur in many ways, either one-way, two-ways, or multi-ways, involving message conveyors and message recipients (Yahya, Mohamed, \& Abdullah, 2007). Effective communication will give a good result, especially to students' academic achievement (Khan, Khan, Zia-Ul-Islam, \& Khan, 2017). According to Katzenmeyer and Moller (2009), effective communication will build a good relationship between teachers and colleagues, teachers and students, and between teachers and parents. Besides, teachers need to practice open communication; that is to receive and to give messages openly and honestly in helping to improve the potential for school excellence.

The diversity dimension in teacher leadership also plays an essential role in students' academic achievement. Diversity can exist in various forms, such as values, beliefs, cultures, religions, races and socioeconomic statuses (Katzenmeyer and Moller, 2009). The uniqueness and diversity elements can shape conducive school culture. Each teacher should respect each other's values and beliefs in realising students' academic excellence. Good teachers will have the initiative to understand the trust and value of colleagues, students, and parents. They will make reflection to improve students' academic achievement. Teachers' knowledge of differences and capabilities that exist can help them work effectively with non-educators. The practice of teacher leadership in the classroom can be seen in the way they manage students and carry out professional teaching skills. It will highlight the teacher leadership skill indirectly and provide evidence that they have high credibility. Teachers with excellent teaching skills are capable of attracting students to follow the teaching and learning process. The final effect of this process is students' outstanding academic results (Katzenmeyer and Moller, 2009). Abu Bakar, Basri and Abas (2013) state that leadership effectiveness should occur at all levels, including in the classroom.

Teachers with excellent teaching skills are also capable of promoting a positive mood in the classroom. Additionally, teachers with a professional level of teaching skills are more approachable as they are always open-minded, looking for new ideas and sharing the expertise that they have with their colleagues. According to Cochran-Smith and Lytle (2006), teaching is a unique and complicated process. Therefore, the teachers need to collaborate when solving problems that arise every day to achieve the vision and mission of the school. Continuous improvement practice is another dimension that related to students' academic achievements. This dimension shows that the degree of excellence or deterioration of a school depends on the leadership skill of all its members in the community. The school community, with a high level of leadership practice, can bring about continuous improvement to the school. Teachers with quality leadership are those who are continually working towards continuous improvement to achieve the set target (Hoy \& Miskel, 2008). Teachers always show proactive attitudes in expanding their potential and, at the same time, enhancing students' academic achievement. These teachers exhibit positive attitudes to improve standards, such as engaging in professional development and learning. 
INTERNATIONAL JOURNAL OF ACADEMIC RESEARCH IN BUSINESS AND SOCIAL SCIENCES Vol. 10, No. 10, 2020, E-ISSN: 2222-6990 @ 2020 HRMARS

Muijs and Harris (2007) state that teacher leadership involves many individuals in the organisation. The involvement of more members of the organisation with a common goal towards the success of the school will make teachers having the potential to become leaders

(Sergiovanni, 2001). Leadership among teachers provides more opportunities for groups or teams to collectively carry out school responsibilities, resources and spaces to address school problems (Yahya, Mohamed, \& Abdullah, 2007). Leadership sharing is essential to maximise leadership roles among teachers (Uribe-Flórez, Al Rawashdeh, \& Morales, 2014). Based on the definition by Katzenmeyer and Moller (2009), teacher leadership refers to teachers who lead in or out of the classroom, identify and engage in learning the community of teachers and leaders as well as influence colleagues towards better education practices. Research on teacher leadership is fundamental nowadays. Studies conducted by many scholars show that teacher leadership gives a variety of positive effects on students' academic achievement through the practice of professional development collaboration in the community of professional learning, communication, enhancement of self-efficacy, motivation and self-esteem of teachers, teaching skills and school culture (Katzenmeyer \& Moller, 2009).

A study conducted by Che Omar (2000) found that teacher leadership level is higher in the effective schools rather than less effective schools. Based on the study of Grant, Gardner, Kajee, Moodley and Samaroo (2008), most schools have begun to apply leadership practices among teachers. However, the process of application is quite slow because of a lack of awareness. Moreover, teachers resist changing as they become more comfortable with the existing condition. This finding is supported by Shukor's (2012), who figured out that teachers are still not ready to accept the concept of teacher leadership. They believe that leadership only involving the school principals. On the other hand, the study of Loh (2011) found that the level of teacher leadership was excellent. The implementation level of teacher leadership can still be improved to ensure better school performance. Foster (2004) proved that teacher leadership had a relationship with the improvement in students' academic achievement. This finding was similar to the results by Berry, Daughtery and Wieder (2010) that teacher leadership has a significant relationship with students' academic achievement. Research by Akert and Martin (2012) shows that the collaborative attitude shown through teacher motivation has improved the academic performance of the students.

Based on the discussion above, we may infer that teacher leadership at school has a strong influence on students' academic achievement through a combination of self-assessment elements and making changes, communication, diversity, teaching skills, continuous improvement and selfhelp organisation (Katzenmeyer \& Moller, 2009; Harris \& Lambert, 2003). Teachers' leadership practices are emphasised in schools because their goals and objectives are to transform teaching and learning culture; and belief the changes help enhance the academic achievement of their students (Crowther, Kaagan, Ferguson \& Hann, 2002). Teacher leadership at schools also helps built school needs, encourage reflection practices and develop the potential and expertise of the teachers in various fields (Bilingsley, 2007).

\section{Students Performance}

Several studies provide evidence that teacher leadership can improve students' academic performance (Greenlee, 2007; Muijs \& Harris, 2003). Besides, effective schools also linked to effective leadership practices (Lieberman, Saxl \& Miles, 2000; Hoy \& Miskel, 2008; Muijs \& Harris, 2003). 
INTERNATIONAL JOURNAL OF ACADEMIC RESEARCH IN BUSINESS AND SOCIAL SCIENCES Vol. 10, No. 10, 2020, E-ISSN: 2222-6990 @ 2020 HRMARS

According to Lambert (2003), teacher leadership as a foundation of the formation of leadership style is one of the factors used to determine the improvement of students' academic achievement. YorkBarr and Duke (2004), define teacher leadership as a process for the good of the organisation itself. The teacher with leadership skills is capable of influencing the colleagues and administrators who share the same interest in improving the methods of teaching and learning as well as achieving the goal of improving student academic achievement. Darling-Hammond \& Richardson (2009) states that teachers need to create a culture of sharing with colleagues. This partnership used as a learning process in addressing issues related to teaching and learning as well as identifying the needs of students.

According to Greenlee (2007), most teachers have started to realise that they are leaders. Teachers become aware of their role as leaders in the classroom. This awareness has facilitated the process of establishing an effective learning organisation because information can be communicated well, while the process of collaboration among teachers can be done and most importantly, the teacher knows the vision and mission to achieve. The main goal of the teachers is to produce successful students and improve the academic performance of the school. Teacher leaders take part in the school's decision making, teacher mentoring, developing curriculum, participating in action research, fostering more cooperation and influencing school changes. Collaboration with colleagues can create a productive school climate and prove that teachers are practising a high level of leadership skills (Katzenmeyer \& Moller, 2009). Some studies provide evidence that teacher leadership study is more important in looking at the development of the quality of education. The results observed through the quality of learning and academic achievement (Katzenmeyer and Moller, 2009; Muijs \& Harris, 2003).

Many studies have provided evidence that students' academic achievement influenced by many factors such as the students themselves, teachers, school organisation and environment factors (Berliner, 1986). Some researchers found, there is a significant relationship between teacher leadership factor and student academic achievement (Pounder, 2014). Yildirim, Acar, Buli, and Sevine (2008) also found a significant impact when teachers assess their students. They also found a substantial influence between the factor of teacher leadership and the decline in student academic achievement. According to Shahril (2010), teachers need to master leadership in the classroom, such as having a high level of knowledge and skills, responsible to the profession and able to guide students towards better academic achievement. Teachers who possess leadership skills and practise it in the classroom provide evidence that they are highly skilled teachers and able to manage themselves and able to communicate with others well (Hook \& Vass, 2000). Othman and Suhid (2010) found that teacher leadership style affects the attitude and behaviour of the students. Apart from that, teacher leadership can stimulate students' interest in learning. The findings are in line with the studies conducted by Che Omar (2000), Siti Aida (2011) and Noor Azam (2012).

\section{Methodology}

This study used a survey questionnaire as a method to collect quantitative data. Instrumentation of Teacher Leadership Self-Assessment (TLSA) developed by Marilyn and Katzenmeyer (2004) used to measure self-assessment and to make changes, communication, diversity, teaching skills, continuous improvement, and independent organisation. Whereas in student's performance, the Overall Grade 
INTERNATIONAL JOURNAL OF ACADEMIC RESEARCH IN BUSINESS AND SOCIAL SCIENCES Vol. 10, No. 10, 2020, E-ISSN: 2222-6990 @ 2020 HRMARS

Value (CGPA) in the Malaysian Certificate of Higher Education (STPM) used as a measurement in this study.

A set of questionnaires that consisted of two parts distributed to the teachers. The first part consisted of the demographic variables of the participants, such as gender, age, years of teaching experiences and academic background. The second part consisted of 42 items that measured the teacher leadership using the Teacher Leadership Self-Assessment (TLSA).

A pilot study was performed prior to the actual data collection to get the reliability of the instruments. Thirty secondary teachers were involved in this stage, and the result showed that the teacher leadership instrument has high reliability, which is at 0.97 . This value showed that this instrument is good and effective with a high value of consistency (Bond \& Fox, 2007).

\section{Participants}

There are 52 teachers from six schools in the district of Raub, Pahang in Malaysia involved in this study. All the teachers are directly involved with form six teaching and learning session. Among the 52 teachers, 23 are male teachers (44.2\%) and 29 are female teachers (55.8\%). In the educational background, $41(78.87 \%)$ respondents are degree holders, while $11(21.2 \%)$ respondents are master's degree holders.

\section{Data Analysis}

Data analysis carried out using Statistical Package for the Social Sciences (SPSS) version 24. An analysis performed to calculate the mean (M) and standard deviation (SD) of the respective constructs. Next, Pearson correlation- $R$ analysis used to determine the relationship between teacher's leadership model and student performance. A mean score between 1.00 to 2.33 (low), 2.34 and 3.66 (moderate) and 3.67 to 5.00 (High) used to interpret the mean score (Abdul Halim, 2005). Meanwhile in Pearson correlation- $R$ analysis, a value between 0.00 and 0.20 (very low), 0.21 to 0.40 (low), 0.41 to 0.70 (moderate), 0.71 to 0.90 (High) and 0.90 to 1.00 (very high) used to interpret the correlation (Azizi et al., 2007). The Overall Grade Value (CGPA) in the Malaysian Certificate of Higher Education (STPM) used to measure student performance. The value of 1.00 to 1.99 (low), 2.00 to 2.99 (medium), 3.00 to 3.99 (Good) and 4.00 (Excellent) as stated in Malaysia Education Board of Inspectors and Quality Assurance (2003).

\section{Results and Discussion The Findings}

The findings showed that the level of teacher leadership is moderate $(M=3.67, S D=0.474)$. The dimension with the highest score was independent organisations $(M=3.41, S D=0.37)$. Furthermore, the dimension of communication ( $M=3.64, S D=0.319)$, the dimension of self-assessment and make changes $(M=3.58, S D=0.325)$, the dimension of continuous improvement $(M=3.56, S D=0.434)$, the dimension of teaching skills $(M=3.53, S D=0.503)$ and the dimension of diversity $(M=3.53, S D=0.379)$. The findings showed that every dimension of teacher leadership is at a moderate level. The result showed that the highest dimension is self-organisation. However, the findings indicated that teachers had implemented teacher leadership practices based on these six dimensions, and these leadership practices can be improved further. 
INTERNATIONAL JOURNAL OF ACADEMIC RESEARCH IN BUSINESS AND SOCIAL SCIENCES Vol. 10, No. 10, 2020, E-ISSN: $2222-6990$ @ 2020 HRMARS

Table 1: level of teacher leadership

\begin{tabular}{lccc}
\hline \multicolumn{1}{c}{ Aspects } & Mean & SD & Level \\
\hline Self-Assessment and Make Changes & 3.58 & 0.325 & moderate \\
Communication & 3.64 & 0.319 & moderate \\
Diversity & 3.53 & 0.379 & moderate \\
Teaching Skills & 3.53 & 0.503 & moderate \\
Continuous Improvement & 3.56 & 0.434 & moderate \\
Independent Organisations & 3.67 & 0.474 & High \\
\hline \multicolumn{1}{c}{ Overall } & $\mathbf{3 . 0 0}$ & $\mathbf{0 . 4 0 6}$ & moderate \\
\hline
\end{tabular}

There are 12 items in measuring self-assessment and make changes dimension. The overall mean score value for all the items in this dimension is relatively moderate $(M=3.19, S D=0.484)$. The item with the highest score documented in the item statement that says; "I get feedback on selfimprovement" ( $M=3.96, S D=0.194)$, while the lowest score recorded in item statement that says "I work towards improving the school culture" $(M=3.33, S D=0.474)$.

Table 2: Mean score and standard deviation to Self-Assessment and Make Changes Dimension in Teacher leadership Model

\begin{tabular}{|c|c|c|c|}
\hline Items & Mean & SD & Level \\
\hline Reflect on every task given to improve myself & 3.54 & 0.503 & Moderate \\
\hline $\begin{array}{l}\text { Understand how strengths and needs for } \\
\text { progress affect the schoolwork. }\end{array}$ & 3.54 & 0.503 & Moderate \\
\hline Understand the content of teaching and learning. & 3.60 & 0.503 & Moderate \\
\hline $\begin{array}{l}\text { Acts in line with values and philosophy when } \\
\text { dealing with students and colleagues. }\end{array}$ & 3.54 & 0.506 & Moderate \\
\hline Getting feedback to improve myself & 3.96 & 0.194 & Moderate \\
\hline $\begin{array}{l}\text { Work ethically at work for professional } \\
\text { achievement. }\end{array}$ & 3.67 & 0.474 & Moderate \\
\hline $\begin{array}{l}\text { Invite my colleagues to work and achieve our } \\
\text { school vision, mission and goals. }\end{array}$ & 3.54 & 0.503 & Moderate \\
\hline $\begin{array}{l}\text { Lead and guide colleagues in completing } \\
\text { assignments. }\end{array}$ & 3.54 & 0.503 & Moderate \\
\hline Involve colleagues when planning changes. & 3.67 & 0.474 & Moderate \\
\hline $\begin{array}{l}\text { Understand the importance of schools and } \\
\text { district or regional culture in improving student } \\
\text { achievement. }\end{array}$ & 3.54 & 0.503 & Moderate \\
\hline Working towards improving school culture. & 3.33 & 0.474 & Moderate \\
\hline $\begin{array}{l}\text { Willing to put the time and energy into building a } \\
\text { team in improving the school. }\end{array}$ & 3.54 & 0.503 & Moderate \\
\hline Overall & 3.19 & 0.484 & Moderate \\
\hline
\end{tabular}

The results for the communication dimension recorded an overall mean score value at a relatively moderate level $(M=3.64, S D=0.490)$. The items that recorded high mean score values are the statements that say "I'm a good listener', "I look for perspectives/ views from others and can 
INTERNATIONAL JOURNAL OF ACADEMIC RESEARCH IN BUSINESS AND SOCIAL SCIENCES Vol. 10 , No. 10, 2020, E-ISSN: 2222-6990 @ 2020 HRMARS

accurately reflect their opinion and feelings," "when helping small groups, I make sure that their members work and be punctual," "when leading the meeting, I can involve almost everyone" and "I use electronic technology effectively to communicate with colleagues" ( $M=3.67, S D=0.541)$.

Table 3: Mean score and standard deviation to Communication Dimension in Teacher leadership Model

\begin{tabular}{|c|c|c|c|}
\hline Items & Mean & SD & Level \\
\hline I'm a good listener & 3.67 & 0.474 & High \\
\hline I adapt my presentation to the audience. & 3.46 & 0.541 & Moderate \\
\hline $\begin{array}{l}\text { seek other perspectives and reflect on their } \\
\text { opinions and views appropriately. }\end{array}$ & 3.67 & 0.474 & High \\
\hline $\begin{array}{l}\text { When it comes to helping small groups, I make } \\
\text { sure the members do their work and submitted } \\
\text { on time. }\end{array}$ & 3.67 & 0.474 & High \\
\hline $\begin{array}{l}\text { I can engage everyone to participate in the } \\
\text { meeting }\end{array}$ & 3.67 & 0.474 & High \\
\hline $\begin{array}{l}\text { I used electronics technology effectively to } \\
\text { communicate with my colleagues }\end{array}$ & 3.67 & 0.474 & High \\
\hline Overall & 3.64 & 0.490 & Moderate \\
\hline
\end{tabular}

In the teacher Diversity dimension, the overall mean score value recorded a relatively moderate level $(M=3.53, S D=0.501)$. The highest mean score value is recorded in the item statement that says, "I take initiative to understand the trust and value of others." The mean score for this item was ( $M=$ 3.67, SD $=0.474)$. This finding showed that teachers have good leadership practices and can work with all parties.

Table 4: Mean score and standard deviation to Diversity Dimension in Teacher leadership Model

\begin{tabular}{lcccc}
\hline Items & Mean & SD & Level \\
\hline $\begin{array}{l}\text { Understand that differences of opinion are due to } \\
\text { differences in culture, religion, race and socioeconomic } \\
\text { status. }\end{array}$ & 3.54 & 0.503 & Moderate \\
$\begin{array}{l}\text { Respect someone's values and beliefs that may differ from } \\
\text { my values \& beliefs. }\end{array}$ & 3.54 & 0.503 & Moderate \\
$\begin{array}{l}\text { Love working with different types of coworkers } \\
\text { Work effectively with non-educators and those with }\end{array}$ & 3.54 & 0.520 & Moderate \\
$\begin{array}{l}\text { different interests. } \\
\text { Took the initiative to understand the beliefs and values of } \\
\text { others. }\end{array}$ & 3.67 & 0.503 & Moderate \\
Willing to share my beliefs even though they are different / & 3.54 & 0.503 & Moderate \\
conflicting with others' beliefs. & & 3.53 & 0.501 & Moderate \\
\hline Overall
\end{tabular}


INTERNATIONAL JOURNAL OF ACADEMIC RESEARCH IN BUSINESS AND SOCIAL SCIENCES Vol. 10, No. 10, 2020, E-ISSN: 2222-6990 @ 2020 HRMARS

The subsequent analysis focuses on teachers' teaching skills dimension. The overall mean score value recorded a relatively moderate level $(M=3.54, S D=0.503)$. This finding indicates that the majority of the teachers practice leadership skills in school. The results showed that teachers who possess excellent leadership practices are capable of working with everyone.

Table 5: Mean score and standard deviation to Teaching Skills Dimension in Teacher leadership Model

\begin{tabular}{|c|c|c|c|}
\hline Items & Mean & SD & Level \\
\hline $\begin{array}{l}\text { Encourage a positive environment in the } \\
\text { classroom }\end{array}$ & 3.54 & 0.503 & Moderate \\
\hline Used Research-Based Instructional (RBI) exercises. & 3.54 & 0.503 & Moderate \\
\hline Make sure all students succeed. & 3.54 & 3.503 & Moderate \\
\hline $\begin{array}{l}\text { Have a reputation as a competent/efficient person } \\
\text { in the class. }\end{array}$ & 3.54 & 0.503 & Moderate \\
\hline $\begin{array}{l}\text { Approachable and always open for sharing with } \\
\text { colleagues }\end{array}$ & 3.54 & 0.503 & Moderate \\
\hline $\begin{array}{l}\text { Act with integrity and justice when working with } \\
\text { students or colleagues. }\end{array}$ & 3.54 & 0.503 & Moderate \\
\hline Overall & 3.54 & 0.503 & Moderate \\
\hline
\end{tabular}

The dimension of continuous improvement comprised of six items. The overall means score documented a relatively moderate level $(M=3.56, S D=0.500)$. Item statement that says, "I am proactive in identifying problems and trying to solve them" recorded the highest score value ( $\mathrm{M}=$ $3.67, \mathrm{SD}=0.474)$, while other items appear to have the same mean score $(M=3.54, S D=0.503)$.

Table 6: Mean score and standard deviation to Continuous Improvement Dimension in Teacher leadership Model

\begin{tabular}{|c|c|c|c|}
\hline Items & Mean & SD & Level \\
\hline $\begin{array}{l}\text { Look up all the relevant information from various } \\
\text { sources before deciding to take action. }\end{array}$ & 3.54 & 0.503 & Moderate \\
\hline $\begin{array}{l}\text { Set goals \& monitor developments to ensure they are } \\
\text { achieved. }\end{array}$ & 3.54 & 0.503 & Moderate \\
\hline Analyse and use exam information in designing. & 3.54 & 0.503 & Moderate \\
\hline Involved in professional learning and development. & 3.54 & 0.503 & Moderate \\
\hline $\begin{array}{l}\text { Proactive in identifying problems \& working to } \\
\text { resolve them. }\end{array}$ & 3.54 & 0.474 & Moderate \\
\hline $\begin{array}{l}\text { Work closely with colleagues, parents and the } \\
\text { community to make changes in the school/district. }\end{array}$ & 3.54 & 0.503 & Moderate \\
\hline Overall & 3.56 & 0.500 & Moderate \\
\hline
\end{tabular}

The results for self-organisation dimension show that the overall score value is at a moderate level $(M=3.67, S D=0.474)$. Here, we may conclude, all the items' mean score in this dimension is at an average level. 
INTERNATIONAL JOURNAL OF ACADEMIC RESEARCH IN BUSINESS AND SOCIAL SCIENCES Vol. 10, No. 10, 2020, E-ISSN: 2222-6990 @ 2020 HRMARS

Table 7: Mean score and standard deviation to self-organisation Dimension in Teacher leadership Model

\begin{tabular}{|c|c|c|c|}
\hline & Mean & SD & Level \\
\hline $\begin{array}{l}\text { Plan and schedule thoroughly to complete tasks and } \\
\text { achieve goals. }\end{array}$ & 3.67 & 0.474 & High \\
\hline $\begin{array}{l}\text { Show confidence when under pressure or in } \\
\text { challenging situations. }\end{array}$ & 3.67 & 0.474 & High \\
\hline Work effectively as a team member. & 3.67 & 0.474 & High \\
\hline $\begin{array}{l}\text { Show initiative and showcase the energy needed to } \\
\text { achieve the desired results. }\end{array}$ & 3.67 & 0.474 & High \\
\hline Prioritises scheduling for important tasks. & 3.67 & 0.474 & High \\
\hline $\begin{array}{l}\text { Provide the right balance between the professional } \\
\& \text { personal aspects of life. }\end{array}$ & 3.67 & 0.474 & High \\
\hline Overall & 3.67 & 0.474 & High \\
\hline
\end{tabular}

The results of the final analysis provide evidence that there is a significant correlation between the level of teacher leadership and academic achievement $(r=0.276, p<0.05)$. The finding offers an indication that teacher leadership (derived from self-assessment and making changes, communication, and diversity, teaching skills, continuous improvement and self-help organisations dimensions) linked to the academic achievement of the students.

\begin{tabular}{lccc}
\hline \multicolumn{1}{c}{ Relationship } & \multicolumn{2}{c}{ Achievement } & Pearson \\
\cline { 2 - 4 } & $\mathbf{R}$ & Sig. & correlation \\
\hline Self-Assessment and Make Changes & 0.259 & 0.032 & Moderate \\
Diversity & 0.282 & 0.021 & Moderate \\
Teaching Skills & 0.309 & 0.013 & Moderate \\
Continuous Improvement & 0.246 & 0.039 & Moderate \\
Independent Organizations & 0.287 & 0.020 & Moderate \\
\hline Overall (Personality) & $\mathbf{0 . 2 7 6}$ & $\mathbf{0 . 0 2 5}$ & Moderate \\
\hline
\end{tabular}

\section{Discussion}

This study used the self-assessment and make changes, diversity, teaching skills, continuous improvement, and independent organisations as a predictor of teacher leadership to students' performance. The findings obtained from the analyses showed that the mean score values for every dimension of teacher leadership factor a relatively moderate. This study is in line with the study of Alibakri and Sadeghi (2014), which showed that the level of teacher leadership in Iran at a moderate level. The dimension that scores the highest mean score value is detected in the teaching skills dimension, while the self-help organisation scores the lowest. The findings also showed that teachers who practice leadership skills are consistent with the recommendation made by Katzenmeyer and Moller (2009).

Overall, the result of the analysis showed that there was a significant relationship at the weak level between teacher leadership and students' academic performance $(r=0.276, p<0.05)$. These findings 
INTERNATIONAL JOURNAL OF ACADEMIC RESEARCH IN BUSINESS AND SOCIAL SCIENCES Vol. 10, No. 10, 2020, E-ISSN: 2222-6990 @ 2020 HRMARS

indicate that teacher leadership for the dimensions of self-assessment and making changes, communication, diversity, teaching skills, continuous improvement and self-organisation are related to student academic achievement. These findings in line with a study conducted by DuFour and DuFour (2010); and Smylie (2010). A recent study by Calderone et al. (2018) also showed that there is a significant relationship between teacher leaders and the student's scores in advanced mathematics and science groups. This result showed that the students' performance would increase if the teachers have higher leadership skills.

According to Che Omar (2000), the elements of self-assessment and making changes can improve teachers' leadership practices. Teachers can reflect on every task done, improve themselves based on feedback and engage colleagues in the process of school formation. Teacher teaching skills dimension has a relatively moderate relationship with student's performance $(r=0.039, p<0.05)$. This study is in line with a study performed by Hill, Rowan and Ball (2005); Stronge, Ward and Grant (2011) showed the student's academic achievement influenced by teacher knowledge and skills. According to Berry, Daughtrey and Wieder (2010), the teacher with positive attitudes, open-minded and willing to share ideas with colleagues will contribute to the increase of student's performance. This sharing of ideas also can help the new teachers to upgrade their instructional skills and practice inside the classroom.

Teachers with a high teaching skills dimension can encourage students' interest to learn and help to improve students' academic achievement (Abu Bakar, Basri, \& Fooi, 2015). This situation illustrated through teachers' attitude where they earnestly ensure that all their students are successful. Barth's study (2001) explains that the teaching skill dimension is a critical element in teacher leadership. Teachers with a high level of teaching skills have positive attitudes, capable of encouraging positive moods in the classroom, provide a wide range of teaching and learning modules, open-minded, and often issue the latest ideas. These teachers are also are the type who work hand in hand with colleagues and share information to develop their leadership practices. A study by Norashikin (2015) showed that teachers with a higher teaching skill could entice the students to learn and help them to improve their academic achievement.

The communication dimension also plays a vital role in influencing the academic achievement of the students. Based on the findings, this means the score value for this dimension is at a moderate level and can be further improved. A good communication teacher can create a comfortable teaching and learning environment. The study by Roy and Hord (2003) shows that teachers with excellent communication skills are capable of establishing good relationships among students and colleagues. This situation indicates that teachers with high leadership skills are competent to attract the students' support and trust. In line with this, a study by Khan, Khan, Zia-Ul-Islam, \& Khan (2017) proves that communication skills have a significant role in students' achievement. Teachers also need to master the diversity dimension. This dimension is one of the factors that significantly influence students' academic achievement, as teachers need to share their beliefs and respect one's value. In the classroom context, teachers' trust and respect are required by the students to form positive relationships. In line with the study of Abu Bakar, Basri and Fooi (2015), teachers serve as leaders to their students to emphasise academic as their primary focus to success. 
INTERNATIONAL JOURNAL OF ACADEMIC RESEARCH IN BUSINESS AND SOCIAL SCIENCES Vol. 10, No. 10, 2020, E-ISSN: 2222-6990 @ 2020 HRMARS

Teacher leadership practices can influence students' interest to learn (Siti Aida, 2011). This finding is in line with the studies conducted by Noor Azam (2012), Loh (2011) as well as Mohammad Aliakbari and Aghdas Sadeghi (2014). The findings of Leiberman (2004) and Murphy (2005) proclaim that students' academic achievement will improve if teachers have a high level of leadership. The main agenda of the education system is to place education in Malaysia on par with the international education system. Hence, efforts to empower the education of this country need to go through a variety of policy changes, acts or regulations to align with our national educational goals. In this case, the impact on the goal is taking students' academic achievement as a benchmark. To achieve this goal, the practice of leadership and personality of teachers should emphasise explicitly. Schools that are led by teachers with a high level of leadership practices will be more likely to produce great students. Therefore, each teacher needs to be equipped with a variety of knowledge on leadership practices and have a positive personality to achieve the goals set.

\section{Conclusion}

The findings of this study can benefit students, teachers, schools and the District of Education Department in improving academic achievement as well as in helping teachers to understand the dimensions of teacher leadership. This study has important implications for teachers in school. The formation and development of teachers' potential as leaders is a process of self-understanding, collaboration with other teachers and with the school. Self-understanding, as a leader, can produce teacher leaders who are committed to their work as they can create action plans for the success of a school. Teachers are considered leaders in the school as they can form a collaborative culture among teachers and students (Katzenmeyer \& Moller, 2009). Hence, it is beneficial to get more information on the influence of teacher leadership on the findings of this study by looking at the relationship with academic achievement at every level of education.

\section{Acknowledgements}

This research partially funded by the Malaysian Ministry of Education: Niche Research Grant Scheme (NRGS-KPM 2014-00001-107-82-4)

\section{References}

Abu Bakar, N., Basri, R., \& Abas, N. (2013). Kepimpinan pengajaran pengetua dan kepimpinan guru. [Principals' teaching leadership and teachers leadership] Proceeding of Post Graduate Seminar in Education (GREDUC 2013), pp. 419-430. Serdang: Universiti Putra Malaysia.

Abu Bakar, N., Basri, R., \& Fooi, S. F. (2015). Teacher leadership relationship with student academic achievement. International Journal of Education and Training (InjET), 1(2), 1-11.

Akert, N., \& Martin, B. (2012). The role of teacher leaders in school improvement through the perceptions of principals and teachers. International Journal of Education, 4(4), 284-299.

Aliakbari, M., \& Sadeghi, A. (2014). Iranian teachers' perceptions of teacher leadership practices in schools. Educational Management Administration \& Leadership, 42(4), 576-592.

Barth, R. S. (2001). Teacher leader. Phi Delta Kappan, 82(6), 443-449.

Berry, B., Daughtrey, A., \& Wieder, A. (2010). Teacher leadership: Leading the way to effective teaching and learning. Center for Teaching Quality. Retrieved from http://www.teachingquality.org/content/teacher-leadership-leading-way-effectiveteaching-and-learning. 
INTERNATIONAL JOURNAL OF ACADEMIC RESEARCH IN BUSINESS AND SOCIAL SCIENCES Vol. 10, No. 10, 2020, E-ISSN: 2222-6990 @ 2020 HRMARS

Berliner, D. C. (1986). In pursuit of the expert pedagogue. Educational researcher, 15(7), 5-13.

Billingsley, B. S. (2007). Recognising and supporting the critical roles of teachers in special education leadership. Exceptionality, 15, 163-176.

Birky, V. D., Shelton, M., \& Headley, S. (2006). An administrator's challenge: Encouraging teachers to be leaders. NASSP Bulletin, 90(2), 87-101.

Bond, T. G., \& Fox, C. M. (2007). Fundamental measurement in the human sciences. Chicago, IL: Institute for Objective Measurement.

Calderone, S., Kent, M. A., \& Green, M. A. (2018). Teacher leadership and Students Achievement: Can the dots connected? Revista Eletrônica de Educação, 12(2), 395-407. http://dx.doi.org/10.14244/198271992525

Che Omar, R. (2000). Kapasiti Kepimpinan Guru, Kepimpinan Sekolah dan Impaknya ke atas Keberkesanan Sekolah. [Teacher Leadership Capacity, School Leadership and Impact on School Effectiveness] Master Thesis. Serdang: UPM.

Cochran-Smith, M., \& Lytle, S. L. (1999). Chapter 8: Relationships of knowledge and practice: Teacher learning in communities. Review of research in education, 24(1), 249-305.

Crowther, F., Kaagan, S. S., Ferguson, M., \& Hann, L. (2002). Developing teacher leaders: How teacher leadership enhances school success. Thousand Oaks, CA: Kirwan.

Danielson, C. (2006). Teacher leadership that strengthens professional practice. Alexandria, VA: Association for Supervision and Curriculum Development.

Darling-Hammond, L., \& Richardson, N. (2009). Teaching-learning: What matters? Educational Leadership, 66(5), 46-53.

DuFour, R., \& DuFour, R. (2010). Raising the bar and closing the gap: Whatever it takes. Solution Tree Press.

Foster, R. (2004). Leadership and secondary school improvement: Case studies of tensions and possibilities. International Journal of Leadership in Education, 8, (1), 35-52. DOI: 10.1080/1360312042000299233.

Grant, C., Gardner, K., Kajee, F., \& Moodley, R. (2008). Teacher leadership: a survey analysis of KwaZulu-Natal teachers' perceptions. South African Journal of Education, 30, (401-419.

Greenlee, B. J. (2007). Building teacher leadership capacity through educational leadership programs. Journal of Research for Educational Leaders, 4(1), 44-74.

Gunter, H. M. (2001). Leaders and leadership in education. London: Paul Chapman Publishing.

Harris, A. (2003). Teacher leadership as distributed leadership: Heresy, fantasy or possibility? School Leadership \& Management, 23(3), 313-324.

Hassan, A., \& Mohd, A. (2011). Teori dan teknik kepimpinan: Panduan aplikasi di tempat kerja. [Leadership theory and technique. Application guide at work.] Selangor: PTS Profesional Publications Sdn. Bhd.

Hill, H. C., Rowan, B., \& Ball, D. L. (2005). Effects of teachers' mathematical knowledge for teaching on student achievement. American educational research journal, 42(2), 371-406.

Hook, P., \& Vass, A. (2000). Confident classroom leadership. London: David Fulton

Hoy, W. K., dan Miskel, C. G. (2008). Educational Administration: Theory, Research and Practice. America: McGraw Hill Companies, Inc.

Ishak, Z., \& Fin, L. S. (2013). Truants' and teachers' behaviors in the classroom. Procedia Social and Behavioral Sciences, 103, 1228-1237. Retrieved from

http://dx.doi.org/10.1016/j.sbspro.2013.10.451 
INTERNATIONAL JOURNAL OF ACADEMIC RESEARCH IN BUSINESS AND SOCIAL SCIENCES

Vol. 10, No. 10, 2020, E-ISSN: 2222-6990 @ 2020 HRMARS

Katzenmeyer, M., \& Moller, G. (2001). Awakening the sleeping giant: Helping teachers develop as leaders. Thousand Oaks: Corwin Press.

Katzenmeyer, M., \& Moller, G. (2009). Awakening the Sleeping Giant: Helping Teachers Develop as Leaders ( $3^{\text {rd }}$ ed.). Thousand Oaks, CA: Corwin.

Khan, A., Khan, S., Zia-Ul-Islam, S., \& Khan, M. (2017). Communication skills of a teacher and its role in the development of the students' academic success. Journal of Education and Practice, 8(1), 18-21.

Lambert, L. (2003). Leadership redefined: An evocative context for teacher leadership. School Leadership \& Management, 23(4),421-430.

Leithwood, K. A., \& Riehl, C. (2003). What we know about successful school leadership. Laboratory for Student Success, Temple University, Philadephia, PA.

Lieberman, A., Saxl, E. R., \& Miles, M. B. (2000). Teacher leadership: Ideology and practice. San Francisco: Josseybass.

Little, J. W. (2003). Constructions of teacher leadership in three periods of policy and reform activism. School Leadership and Management, 23, 201-419. DOI: 10.1080/1363243032000150944

Loh, K. C. (2011). Kepemimpinan guru di sebuah sekolah kerajaan di Papar: Kes SMK Majakir. [Teacher leadership in a government school in Papar: SMK Majakir] 16th National Seminar on Educational Management and Leadership. Institute Aminuddin Baki.

Muijs, D., \& Harris, A. (2003). Teacher leadership - Improvement through empowerment? An overview of the literature. Educational Management \& Administration, 31(4), 437-448.

Muijs, D., \& Harris, A. (2007) Teacher leadership in action: Three case studies of contrasting schools', Education Management and Administration, 35, 111-134.

Murphy, J. (2005). Connecting teacher leadership and school improvement. Thousand Oaks, CA: Corwin Press.

Norashikin, A. B., Ramli, B., \& Foo S. F. (2015). Hubungan Kepimpinan Guru dengan Pencapaian Akademik Pelajar. International Journal of Education and Training (InjET), 1(2), 1-11.

Azam, N. I. (2012). Kepimpinan Guru Mempengaruhi Sikap Pelajar Sekolah Menengah Daerah Segamat. [Teacher Leadership Affects Students' Attitudes of Segamat District Secondary School] Master Thesis. Skudai: UTM.

Othman, M. K., \& Suhid, A. (2010). Peranan sekolah dan guru dalam pembangunan nilai pelajar menerusi penerapan nilai murni: Satu sorotan. [The role of schools and teachers in the development of student values through the application of noble values: A literature review] MALIM-SEA Journal of General Studies, 11, 117-130. Retrieved from www.myjournal. my/filebank/published_article/23385/Artikel_9.pdf

Pounder, J. (2014). Quality teaching through transformational classroom leadership. Quality Assurance in Education, 22(3), 273-285. Retrieved from https://doi.org/10.1108/QAE-122013-0048

Roy, P., \& Hord, S. (2003). Moving NSDC's staff development standards into practice: Innovation configurations. National Staff Development Council, Marsha Spring, CO: Spring \& Company.

Sergiovanni, T. J. (2001). Leadership: What's in it for schools? London, UK: Routledge.

Smylie, M. A. (2009). Continuous school improvement. Corwin Press.

Stronge, J. H., Ward, T. J., \& Grant, L. W. (2011). What makes good teachers good? A cross-case analysis of the connection between teacher effectiveness and student achievement. Journal of teacher Education, 62(4), 339-355. 
INTERNATIONAL JOURNAL OF ACADEMIC RESEARCH IN BUSINESS AND SOCIAL SCIENCES

Vol. 10, No. 10, 2020, E-ISSN: 2222-6990 @ 2020 HRMARS

Syukor, S. A. (2012). Konsep Kepimpinan Guru dalam Kalangan Guru di Tiga Buah Sekolah Menengah di Segamat. [The concept of leadership in teachers in the three schools in Segamat.] Master Thesis. Skudai: UTM.

Uribe-Flórez, L. J., Al-Rawashdeh, A., Morales, S. (2014). Perceptions about teacher leadership: Do teacher leaders and administrators share a common ground? Journal of International Education and Leadership, 4(1), 1-15.

Yahya, A. S., Mohamed, A. R., \& Abdullah, A. G. (2007). Guru sebagai pemimpin. [Teacher as leaders] Selangor. PTS Professional Publishing Sdn. Bhd.

Yildirim, O., Acar, A. C., Buli, S., \& Sevine, L. (2008, January). Relationships between teachers' perceived leadership style, students' learning style, and academic achievement: A study on high school students. Educational Psychology, 28(1), 73-81. DOI:10.1080/01443410701417945

York-Barr, J., \& Duke, K. (2004). What do we know about teacher leadership? Findings from two decades of scholarship. Review of Educational Research, 74(3), 255-316.

Yusof, H., Min, Z. M., Jalil, N. A., Noor, M. A. M., \& Yusof, R. (2018). Teacher leadership and its relationship with students' academic achievement. International Journal of Academic Research in Business and Social Sciences, 8(9), 1551-1562. 